\title{
BIOLOGY OF SOFT TISSUE REPAIR: GINGIVAL EPITHELIUM IN WOUND HEALING AND ATTACHMENT TO THE TOOTH AND ABUTMENT SURFACE
}

\author{
S. Gibbs ${ }^{1,2, *}$, S. Roffel ${ }^{2}$, M. Meyer ${ }^{3}$ and A. Gasser ${ }^{3}$ \\ ${ }^{1}$ Department of Molecular Cell Biology and Immunology, VU University Medical Centre, \\ Amsterdam UMC, the Netherlands \\ ${ }^{2}$ Department of Oral Cell Biology, Academic Centre for Dentistry Amsterdam (ACTA), \\ University of Amsterdam and Vrije Universiteit Amsterdam, Amsterdam, the Netherlands \\ ${ }^{3}$ Nobel Biocare Services AG, Kloten, Switzerland
}

\begin{abstract}
Epithelium attachment to the tooth or abutment surface is necessary to form a biological seal preventing pathogens and irritants from penetrating the body and reaching the underlying soft tissues and bone, which in turn can lead to inflammation and subsequent bone resorption. The present review investigated oral wound closure and the role of micro-environment, saliva, crevicular fluid and microbiota in wound healing. The importance of the junctional epithelium (peri-implant epithelium) attachment to the abutment surface was investigated. Current research focuses on macro-design, surface-topography, surface-chemistry, materials, coatings and wettability to enhance attachment, since these optimised surface properties are expected to promote keratinocyte attachment and spreading through hemi-desmosome formation. Detailed studies describing the extent of junctional epithelium attachment-e.g. barrier function, hemi-desmosomes, epithelium quality, composition of the external basement membrane or ability of the epithelium to resist microbial penetration and colonisation - are not yet reported in animals due to ethical considerations, scalability, expense, technical challenges and limited availability of antibodies. In vitro studies generally include relatively simple 2D culture models, which lack the complexity required to draw relevant conclusions. Additionally, human organotypic 3D mucosa models are being developed. The present review concluded that more research using these organotypic mucosa models may identify relevant parameters involved in soft-tissueabutment interactions, which could be used to study different macro-shapes and surface modifications. Such studies would bridge the gap between clinical, animal and traditional in vitro cell culture studies supporting development of abutments aiming at improved clinical performance.
\end{abstract}

Keywords: Oral epithelium, junctional epithelium, abutment, implant, attachment, biological seal, surface, basement membrane, saliva, crevicular fluid.

*Address for correspondence: Susan Gibbs, Department of Oral Cell Biology, Academic Centre for Dentistry Amsterdam (ACTA), Gustav Mahlerlaan 3004, 1081 LA Amsterdam, the Netherlands

Email: s.gibbs@acta.nl

Copyright policy: This article is distributed in accordance with Creative Commons Attribution Licence (http://creativecommons.org/licenses/by-sa/4.0/).

\section{Introduction}

Novel materials and surface modifications are being continuously developed to improve clinical performance of dental abutments and implants. A dental implant is a medical device that interfaces with the bone of the jaw. Therefore, dental implants are designed to promote optimal attachment to the bone (osseointegration). The abutment is a connecting element between the implant and the dental prosthetic (e.g. bridge or crown) which is designed to support gingival soft tissue attachment and, in particular, epithelial tissue attachment. The epithelium forms the outermost barrier between the organism and the environment and is in contact with the vascularised connective tissue. The connective tissue provides tensile strength to the gingiva and nutrients to the epithelium and lies above the bone. Epithelial attachment to the abutment surface is required to form a tight barrier to protect the underlying bone from microorganisms and other pathogenic insults. Pathogenic microbial colonisation can lead to peri- 
implantitis, characterised by gingival recession, inflammation and bone resorption, often culminating in dental implant failure [see extensive reviews of clinical studies (Berglundh et al., 2019; Hammerle et al., 2012; Lang and Lindhe, 2015; Sculean et al., 2014)]. A balance is maintained thanks to the barrier function of the epithelium and the microbiome, which is aided by the multitude of wound healing and antimicrobial molecules in the saliva (Brand et al., 2014). The present review focuses on the biology of soft tissue repair in the context of the gingival epithelium role in wound healing and attachment to the tooth and abutment surface.

\section{Biology of the gingiva}

The gingiva consists of an outer, stratified squamous epithelium in direct contact with an underlying, dense connective tissue called the lamina propria, which contains blood vessels, structural fibres, nerves, fibroblasts and other cell types (Winning and Townsend, 2000). The epithelium of the free gingiva (coronal to the cementoenamel junction) is composed of: (i) oral epithelium, which faces the oral cavity (this comprises the free gingiva and the attached gingiva); (ii) oral sulcular epithelium, which faces the tooth, but does not contact it; (iii) junctional epithelium, which contacts the enamel of the tooth (Fig. 1, Table 1 and Table 2) (Bosshardt and Lang, 2005; Gibbs and Ponec, 2000; Jiang et al., 2014; Lang and Lindhe, 2015; Larjava et al., 2011a; Presland and Dale, 2000; Vriens et al., 2008). The different types of gingival epithelia differ from one another in their function and, therefore, in some of their histological characteristics. The keratinised oral epithelium is adapted to its masticatory function. Resistance to mechanical injury is facilitated predominantly by i) abundant intercellular junctions, mostly desmosomes, that hold the cells tightly together, ii) undulations in the epithelium and connective tissue (rete ridges), iii) stratum corneum. The stratum corneum and the relatively narrow intercellular spaces also contribute to the low permeability as compared to the non-keratinised lining mucosa of the junctional and sulcular epithelium (Presland and Jurevic, 2002; Winning and Townsend, 2000). The gingival margin is the transition epithelium between the keratinised oral and the non-keratinised sulcular epithelium (Fig. 1). The sulcular epithelium lines the sulcus, which is the space between the gingiva and the enamel surface of the tooth. Continuing from the sulcular epithelium is the very thin non-keratinised junctional epithelium, which attaches through the internal basal lamina to the enamel of the tooth. Therefore, the junctional epithelium plays an extremely important role, not only in attaching the tooth to the surrounding soft tissues but also in forming a tight biological seal, with accompanying barrier properties, against microbial colonisation. Crevicular fluid, which contains many wound healing and anti-microbial molecules, is continuously secreted from the junctional and sulcular epithelium into the sulcus (Lang and Lindhe, 2015; Winning and Townsend, 2000).

On a molecular level, the different types of epithelia can be distinguished by their very specific
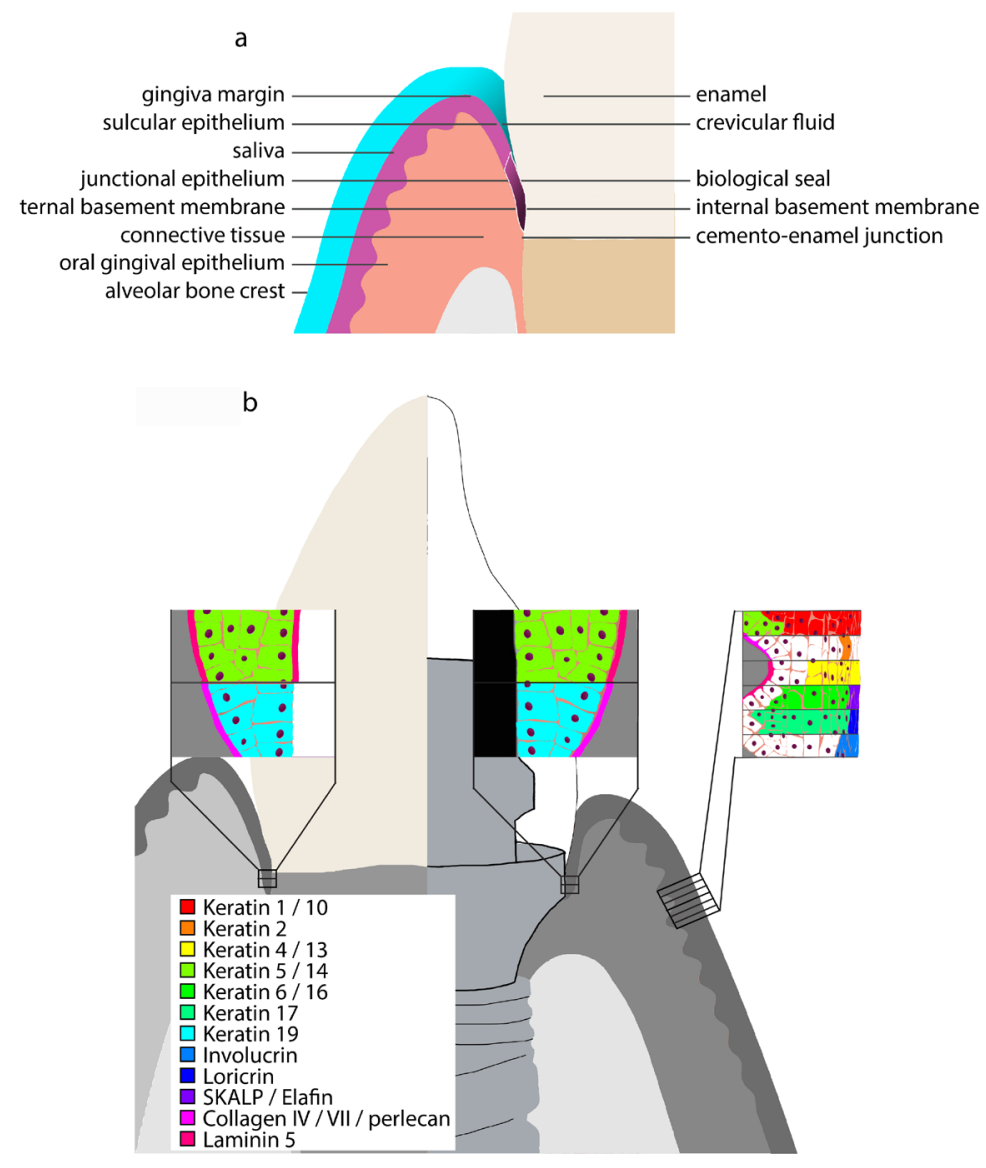

Fig. 1. Gingiva histology and keratin expression. (a) Gingiva histology and attachment to the tooth surface. (b) Differential keratin expression in gingival and junctional epithelium adjacent to tooth (left) and abutment surface (right) is illustrated. 
Table 1. Histological characteristics of skin and oral mucosa epithelia. ++: abundant; +: present; -: absent; +/-: intermediate; ?: not known; empty: not applicable. References in main text (Bosshardt and Lang, 2005; Gibbs and Ponec, 2000; Jiang et al., 2014; Larjava et al., 2011a; Presland and Dale, 2000; Presland and Jurevic, 2002; Vriens et al., 2008).

\begin{tabular}{|c|c|c|c|c|c|c|}
\hline & Skin & $\begin{array}{c}\text { Outer } \\
\text { gingiva } \\
\text { epithelium }\end{array}$ & $\begin{array}{c}\text { Gingiva } \\
\text { margin }\end{array}$ & $\begin{array}{c}\text { Sulcular } \\
\text { epithelium }\end{array}$ & $\begin{array}{c}\text { Junctional } \\
\text { epithelium }\end{array}$ & $\begin{array}{c}\text { Peri-implant } \\
\text { epithelium }\end{array}$ \\
\hline Micro-environment & air & saliva & saliva & $\begin{array}{c}\text { crevicular } \\
\text { fluid }\end{array}$ & tooth & implant \\
\hline $\begin{array}{c}\text { Epithelium } \\
\text { characteristics }\end{array}$ & ++ & $+/-$ & - & - & - \\
\hline $\begin{array}{c}\text { Ortho-keratinsed } \\
\text { Para-keratinised }\end{array}$ & - & - & $+/-$ & + & + & + \\
\hline $\begin{array}{c}\text { Rete ridges } \\
\text { cell layers }\end{array}$ & $5-8$ & $20-30$ & $20-30$ & $15-30$ & $1-30$ & ? \\
\hline $\begin{array}{c}\text { Number of epithelium } \\
\text { cell layers }\end{array}$ & + & + & +6 & $?$ & $1-6$ & $?$ \\
\hline $\begin{array}{c}\text { Number of coronal } \\
\text { layers }\end{array}$ & $25-40$ & $10-12$ & +30 & $?$ \\
\hline \begin{tabular}{c} 
Turnover (d) \\
\hline
\end{tabular}
\end{tabular}

keratin expression profiles (Fig. 1, Table 2) (Gibbs and Ponec, 2000; Jiang et al., 2014; Presland and Dale, 2000; Vriens et al., 2008). For all types of epithelia, cell division takes place in the stratum basale (Gibbs and Ponec, 2000). After dividing, committed cells undergo a differentiation process that leads to expression of structural keratin proteins and loss of intracellular organelles as cells move upwards, begin to flatten and, eventually, are sloughed off the surface (Presland and Jurevic, 2002). Whereas (ortho-) keratinised masticatory mucosae lose their nuclei, non-keratinised (or para-keratinised) lining mucosae retain their nuclei (Lang and Lindhe, 2015).

Junctional epithelium attachment to the tooth: a biological seal preventing infection

The non-keratinised junctional epithelium firmly attaches the gingiva to the enamel of the tooth. This biological seal forms a barrier against pathogens whilst still enabling diffusion of molecules. In a healthy situation, it averages approximately $2 \mathrm{~mm}$ in height. The junctional epithelium tapers off in the apical direction ranging from 15-30 cell-layers coronally to 1-3 cell-layers apically. It is connected to the underlying lamina propria through the external basal lamina and to the tooth through the internal basal lamina, both through hemi-desmosomes (Larjava et al., 2011a). The external basal lamina is composed of typical basement membrane proteins, such as collagens IV and VII, laminins, heparin sulphate proteoglycans, perlecans and nidogen, whereas the internal basal lamina has different features. For example, it lacks collagens IV and VII, most laminin isoforms (except for laminin 5), perlecan and lamina fibroreticularis (Bosshardt and Lang, 2005). Therefore, the two different surfaces of the junctional epithelium can be easily distinguished from each other by immunohistochemical staining. Notably, the junctional epithelial cells are interconnected by relatively few desmosomes and gap junctions so that the fluid-filled intercellular spaces formed within are wider as compared to those within the oral gingiva and sulcular epithelium. These features account for the high permeability of the junctional epithelium and permit a variety of mononuclear leukocytes (neutrophils, macrophages, lymphocytes and antigen-presenting cells) to fill these intercellular spaces. The intercellular spaces also provide a pathway for migration of many leukocytes into the crevicular fluid (Bosshardt and Lang, 2005). Whereas a lot of attention has been paid to optimal osseointegration and connective tissue attachment to implant materials and abutments, very little is known about the importance of optimal function and attachment of the junctional epithelium to these materials (Hammerle et al., 2012; Hammerle et al., 2014; Salvi et al., 2015; Sculean et al., 2014).

\section{Wound healing after tooth extraction}

Soft-tissue healing of oral wounds after tooth extraction follows a similar pattern of healing to skin wounds and both involve the following phases: haemostasis, 
Table 2. Expression of epithelium-related proteins and basement membrane proteins in skin and oral mucosa. BL: basal layer; SB: suprabasal; SSU: upper spinous layer; SG: stratum granulosum; BM: basement membrane; +: present; -: absent; ?: not known; empty: not applicable. References in main text (Bosshardt and Lang, 2005; Gibbs and Ponec, 2000; Jiang et al., 2014; Larjava et al., 2011a; Presland and Dale, 2000; Presland and Jurevic, 2002; Vriens et al., 2008).

\begin{tabular}{|c|c|c|c|c|c|c|}
\hline & Skin & $\begin{array}{c}\text { Outer } \\
\text { gingiva } \\
\text { epithelium }\end{array}$ & $\begin{array}{l}\text { Gingiva } \\
\text { margin }\end{array}$ & $\begin{array}{c}\text { Sulcular } \\
\text { epithelium }\end{array}$ & $\begin{array}{l}\text { Junctional } \\
\text { epithelium }\end{array}$ & $\begin{array}{c}\text { Peri- } \\
\text { implant } \\
\text { epithelium }\end{array}$ \\
\hline \multicolumn{7}{|l|}{$\begin{array}{c}\text { Epithelial differentiation } \\
\text { proteins }\end{array}$} \\
\hline Keratin 1 and 10 & SB & SSU, SG & + & - & - & $?$ \\
\hline Keratin 2(e and p) & $\mathrm{K} 2 \mathrm{e}, \mathrm{SB}$ & $\mathrm{K} 2 \mathrm{p}, \mathrm{SB}$ & $?$ & $?$ & $?$ & $?$ \\
\hline Keratin 4 & - & SB & SB & + & - & $?$ \\
\hline Keratin 5 and 14 & BL & BL & + & + & + & $?$ \\
\hline Keratin 6 & - & SSU, SG & + & + & $?$ & $?$ \\
\hline Keratin 8 and 18 & - & - & - & - & + & $?$ \\
\hline Keratin 13 & - & SB & + & + & + & $?$ \\
\hline Keratin 16 & - & SB & SB & + & + & \\
\hline Keratin 17 & - & SSU, SG & + & + & + & $?$ \\
\hline Keratin 19 & $?$ & - & - & + & + & $?$ \\
\hline Involucrin & SG & SSU, SG & $?$ & $?$ & $?$ & $?$ \\
\hline Loricrin & SG & SSU, SG & $?$ & $?$ & $?$ & $?$ \\
\hline SKALP/elafin & SG & SSU, SG & $?$ & $?$ & $?$ & $?$ \\
\hline $\begin{array}{c}\text { Basement membrane } \\
\text { proteins }\end{array}$ & + & + & + & + & + & + \\
\hline $\begin{array}{c}\text { External BM (adjacent to } \\
\text { lamina propria) }\end{array}$ & + & + & + & + & + & + \\
\hline $\begin{array}{c}\text { Collagen IV and VII, } \\
\text { perlecan }\end{array}$ & + & + & + & $?$ & + & $?$ \\
\hline Laminin 5 & + & + & + & + & + & $?$ \\
\hline $\begin{array}{c}\text { Epithelial attachment } \\
\text { through hemi-desmosomes }\end{array}$ & + & + & + & $?$ & + & + \\
\hline $\begin{array}{c}\text { Internal BM (adjacent to } \\
\text { tooth / implant) }\end{array}$ & - & - & - & - & + & $?$ \\
\hline $\begin{array}{c}\text { Collagen IV and VII, laminin } \\
\text { 1, perlecan } \\
\end{array}$ & & & & $?$ & - & $?$ \\
\hline Laminin 5 & & & & $?$ & + & $?$ \\
\hline $\begin{array}{c}\text { Epithelial attachment } \\
\text { through hemi-desmosomes }\end{array}$ & & & & + & + & $?$ \\
\hline
\end{tabular}


inflammation, cell proliferation, extracellular matrix deposition and matrix remodelling. Therefore, the extensive information available on skin wound healing is often used to increase the insight into oral wound healing (Engeland et al., 2006; Glim et al., 2013; Larjava et al., 2011b; Sculean et al., 2014). However, clear differences exist between oral and skin wound healing. Despite the fact that oral mucosa has a warm moist environment ideal for bacterial growth, healing of the oral mucosa is superior to that of skin: wounds heal faster, rarely become infected and rarely form adverse scars (Amerongen and Veerman, 2002; Glim et al., 2013; Sculean et al., 2014). These differences between skin and mucosa may be explained by i) different intrinsic properties of the cells within the skin and oral mucosa (e.g. keratinocytes, fibroblasts, different state of immunity); ii) environmental factors (e.g. saliva, crevicular fluid, moisture, temperature); iii) commensal and pathogenic biofilm. Additionally, the better blood microcirculation in the oral mucosa, enhancing nutrient and inflammatory cell access to the wound site, is considered to be beneficial for wound healing. Both intrinsic properties of the cells within the oral mucosa as well as interactions with the surrounding tissue environment and immune system have been identified, which might in part explain the superior oral wound healing (Barrientos et al., 2008; Boink et al., 2016; Boink et al., 2018; Chen et al., 2010; Feller et al., 2013; Glim et al., 2013; IglesiasBartolome et al., 2018; Kosten et al., 2015; Kosten et al., 2017; Larjava et al., 2011a; Szpaderska et al., 2005; Szpaderska et al., 2003). Kroeze et al. (2012) identified an autocrine feedback loop regulating reepithelialisation through chemokine receptors CCR1, CCR10, CXCR1, CXCR2 and CXCR3 after wounding of the epidermis. It has yet to be determined whether the same cellular mechanisms are involved in reepithelialisation of the gingiva. Interestingly, the autocrine feedback loops regulating skin and gingival fibroblast proliferation and migration are different, with CCR3 and CCR4 being predominant in the gingiva and CCR5 being predominant in the skin. Notably, CCR5 is not expressed by cultured gingival fibroblasts (Buskermolen et al., 2017; Kroeze et al., 2012). Taken together, these data suggest that oral mucosa epithelium is intrinsically primed to repair through different mechanisms from that observed in skin, but the large number of epithelial cell layers characteristic of many types of oral mucosa subject to extreme mechanical load and pathogen exposure is most probably regulated by extrinsic factors in the microenvironment. Indeed, Shang et al. (2018) have recently shown that commensal oral biofilm has a beneficial influence on oral mucosa barrier function by increasing keratinocyte proliferation, stratification and expression of host-defence proteins.

\section{Saliva and crevicular fluid}

A major contributor to oral mucosa wound healing is the presence of saliva in the oral cavity and crevicular fluid in the sulcus (Amerongen and Veerman, 2002; Ashcroft et al., 2000; Bosshardt et al., 2015; Brand et al., 2014; Dawes et al., 2015; Ghosh et al., 2011; Henskens et al., 1996; Koczulla et al., 2003; Playford and Macdonald, 1997; Prodan et al., 2015). In addition to its lubricating function, saliva contains a rich cocktail of proteins ( $>1,000$ proteins) functioning synergistically to promote cell division, enhance cell migration and, importantly, provide anti-microbial activity supporting an healthy oral microflora (Brand et al., 2014). For example, saliva's defensins, LL37, histatins, immunoglobulins $\mathrm{A}$ and mucins protect against the formation of a pathogenic microbiome, whereas cytokines, chemokines and growth factors directly enhance wound closure. Also, histatins, a class of histidine-rich peptides with anti-microbial and anti-fungal properties, are present in the saliva, albeit only in the saliva secreted by humans and some non-human primates (Oppenheim et al., 1988; Padovan et al., 2010). By regulating the wound healing response, immune response and microbiota, saliva may possibly contribute to the almost scar-free healing in the oral cavity, although further conclusive studies are still required (Boink et al., 2017; Brand et al., 2014; Iglesias-Bartolome et al., 2018; Mohanty et al., 2015; Oudhoff et al., 2008).The wound healing

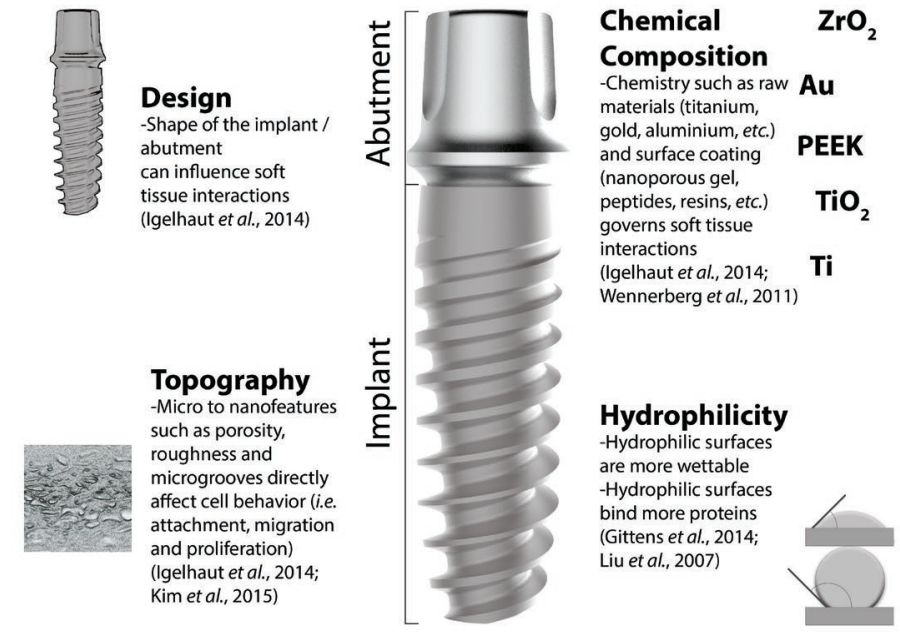

Fig. 2. Material characteristics under investigation. A representative abutment and implant system are shown. 
a

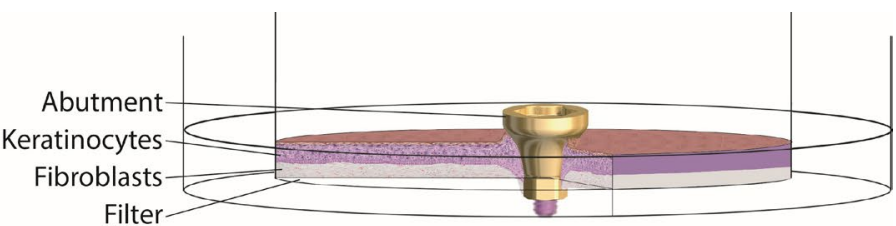

b
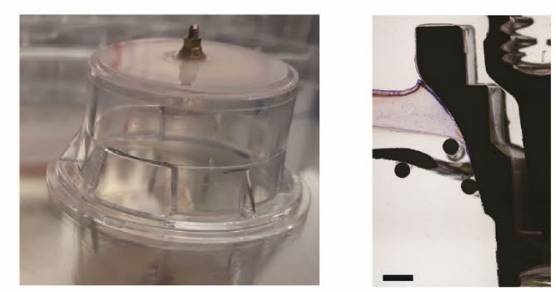

c $\mathrm{H} / \mathrm{E}$

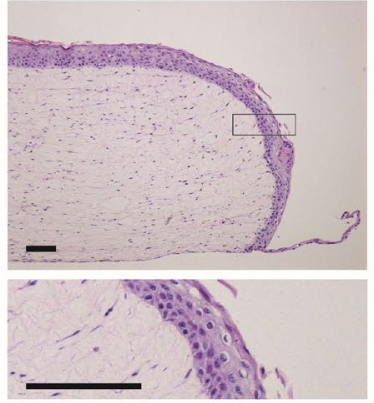

d Ki67

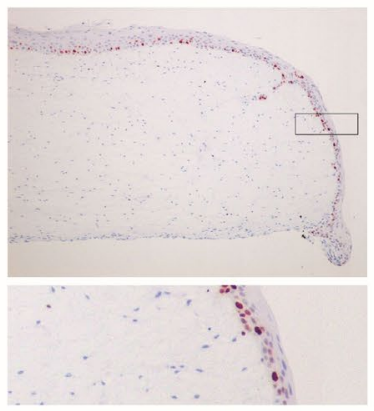

e Laminin 5

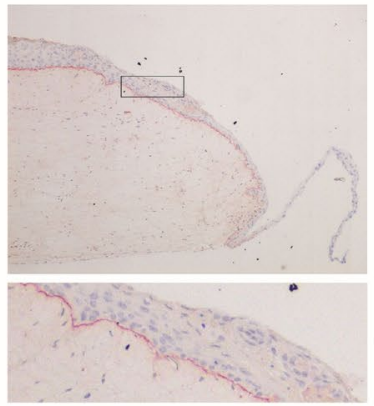

f Col IV

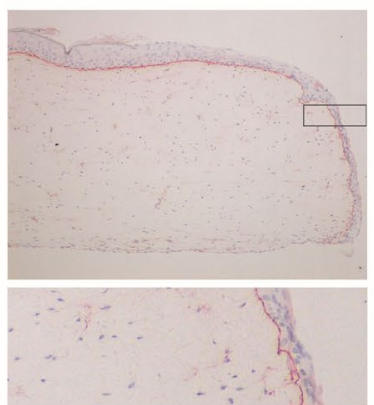

- abutment
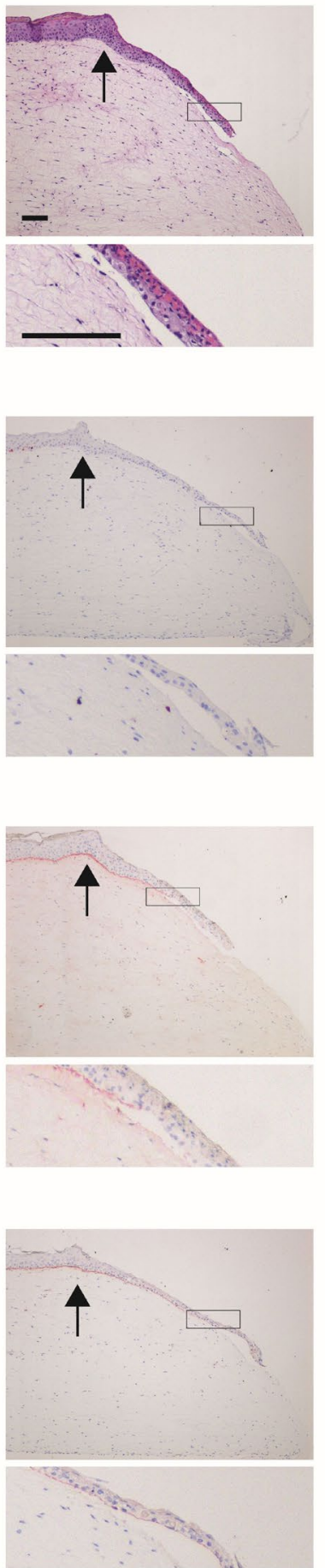

+ abutment
Fig. 3. Reconstructed human gingiva model (RHG), consisting of stratified epithelium on a fibroblast-populated hydrogel, for investigating abutmentsoft tissue interactions. An anodised titanium abutment inserted into an RHG, which is cultured exposed to the air on a porous Transwell membrane for $10 \mathrm{~d}$. (a) Scheme showing experimental design. (b) Left shows macroscopic view of $20 \mathrm{~mm}$ diameter Transwell culture system at time of RHG harvest; centre and right show histomorphometric tissue-abutment section with downgrowing epithelium attachment to abutment surface (scale bar $=500 \mu \mathrm{m}$ ). (c-f) Haematoxylin and eosin staining $(\mathrm{H} / \mathrm{E})$ and immunohistochemical analysis of down-growing RHG epithelium in the absence of an abutment (- abutment) or adjacent to the abutment surface (+ abutment; abutment is gently removed before tissue fixation). H/E shows a stratified and cornified gingiva epithelium to the left of the arrow. Down-growing epithelium can be observed to the right of the arrow. Ki67: proliferating keratinocytes; laminin 5 and collagen IV (Col VI): basement membrane proteins (red immune-staining). Black box is represented by higher magnification image below; scale bar $=100 \mu \mathrm{m}$. For full experimental details see Roffel et al. (2019). Unpublished data and data derived from Roffel et al. (2019) are shown. 
properties of saliva were already acknowledged by the ancient Greeks 2000 years ago, when they applied snake saliva to open wounds to enhance cutaneous wound healing (Angeletti et al., 1992). Furthermore, modern research has shown that snake saliva contains a rich source of substances such as epidermal growth factors. Also, rats allowed to lick burn wounds show enhanced wound healing as compared to controls (Bodner and Dayan, 1995; Bodner et al., 1993; Jahovic et al., 2004), indicating that saliva is not only beneficial to the oral mucosa but also for skin healing. Saliva also creates a moist wound healing environment that reduces wound surface necrosis, prevents wound desiccation, activates enzymes needed for debridement and stimulates cell proliferation and migration (Kannon and Garrett, 1995). In contrast, under dry mouth conditions, pre-clinical evidence shows that oral wound healing is slower in a rat model with salivary gland hypofunction (Dayan et al., 1992). Direct clinical evidence is scarce, as salivary hypofunction is often linked to older age (where age itself influences wound healing) and/or medicine side effects. The Sjogren's syndrome is an autoimmune disease with additional symptoms of a dry mouth. Consequently, it is not conclusive whether the impaired wound healing is a direct result of dryness or due to the immune system malfunction (Khan and Shirlaw, 2016).

The gingival sulcus is bathed in crevicular fluid, a serum exudate originating from the periodontal sulcus, which contains all the key molecular (cytokines, antibodies and complement proteins) and cellular (e.g. plasma cells, leukocytes) components necessary for invoking an immune response and preventing tissue invasion by microbes (Barros et al., 2016; Faot et al., 2015). Furthermore, it contains many wound healing mediators such as growth factors, cytokines and tissue remodelling factors, e.g. matrix metalloproteinases (Barros et al., 2016). Therefore, in many aspects, the crevicular fluid resembles a variant of saliva that has more potent wound healing and tissue defence properties.

\section{Biofilm}

Oral health is mediated by an intricate balance between commensal and (opportunistic) pathogenic biofilm, tightly regulated by the composition of human saliva and other host (immune) factors. An imbalance can result in a negative dysbiosis (Janus et al., 2015; Krom and Oskam, 2014; Schlecht et al., 2015; Zaura et al., 2014). Oral wounds provide viable niches for microbial biofilms and, due to their open access to the external environment, microbial colonisation is inevitable. The effect of the microbial ecology on oral wound healing seems obvious; yet, it is still poorly understood. While some commensal bacteria can cause infections, in general these biofilms display low levels of virulence (low morbidity) and occupy a space that otherwise would be occupied by pathogenic bacteria. How they affect wound healing is presently unclear. However, it can be expected that there is an intimate crosstalk between the microbiota and residential cells as well as infiltrating immune cells, which together determine the rate and quality of wound healing (Ellebrecht et al., 2016; Srinivas et al., 2013; Trengove et al., 1996). Buskermolen et al. (2018), when comparing oral commensal and pathogenic biofilms, observed that the pathogenic biofilm supresses the innate immune response (inflammatory cytokine release), suggesting that an early immune evasion is taking place in the organotypic gingival mucosa tissue equivalents. Furthermore, Shang et al. (2018), using gingival tissue equivalents, showed that a commensal multi-species oral biofilm promotes an organised epithelial stratification and oral barrier function by increasing epithelial cell layers' number, cell proliferation and expression of host anti-microbial protein expression [elafin, human beta defensin (HBD) 2 and HBD3).

\section{Peri-implant healing and junctional epithelium attachment to abutment surface}

Peri-implant soft and hard tissues form as a result of wound healing, with attachment and maturation of the soft tissues to the abutment being established 6-8 weeks after surgery (Salvi et al., 2015). Periimplant wound healing has essential differences from wound healing after tooth extraction, since optimal restoration of the biological seal around the abutment and osseointegration of the implant needs to be achieved rather than wound closure alone (Sculean et al., 2014). Onset and resolution of inflammation during the inflammatory phase of wound healing together with soft tissue attachment are essential to avoid peri-implantitis and achieve long-term implant success (Tomasi et al., 2016). For similar reasons to those described earlier, saliva and biofilm are expected to influence rate and quality of wound healing. Bielemann et al. (2018) extensively reviewed wound healing biomarkers detected in peri-implant crevicular fluid up to 16 weeks after placing the implant. This peri-implant crevicular fluid contains many molecules involved in bone remodelling [e.g. bone morphogenetic proteins (BMPs), receptor activator of nuclear factor kappa-B ligand (RANKL), alkaline phosphatase (ALP), etc.] as well as inflammatory cytokines [e.g. interleukin (IL)-6, IL-8, tumour necrosis factor alpha (TNF- $\alpha$ ), monocyte chemoattractant protein 1 (MCP-1), etc.]. Furthermore, Tomasi et al. (2016) described the resolution of inflammatory cells (macrophages and polymorphonuclear cells) within human connective tissue adjacent to the abutment surface, during an 8-week study period.

New implant materials developed to promote osseointegration have received a lot of attention. Recently, the focus has extended towards the development of abutment materials supporting gingival soft tissue attachment, since it is now recognised that a functional biological seal is essential 
a Keratin 4

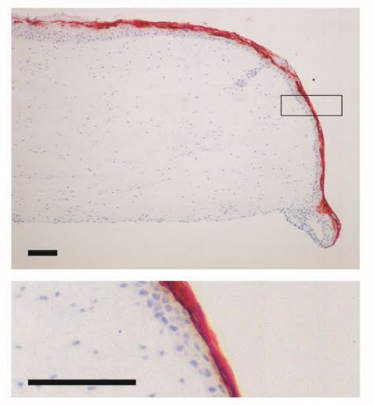

c Keratin 10

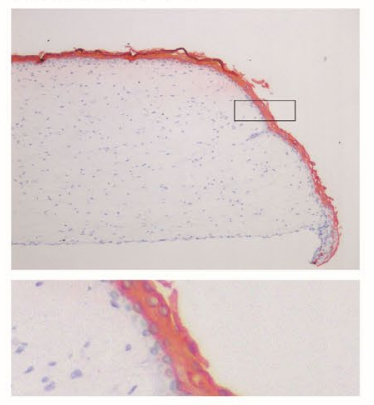

e Keratin 14

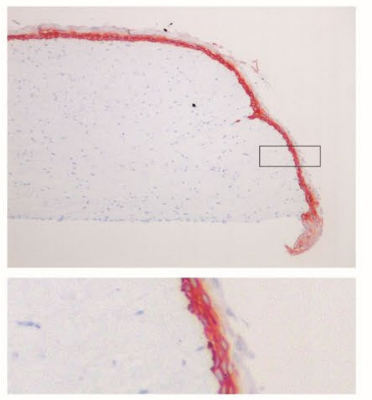

g Keratin 19

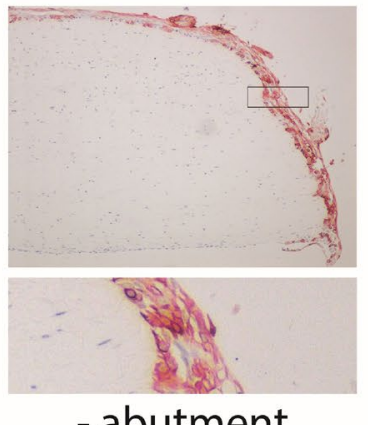

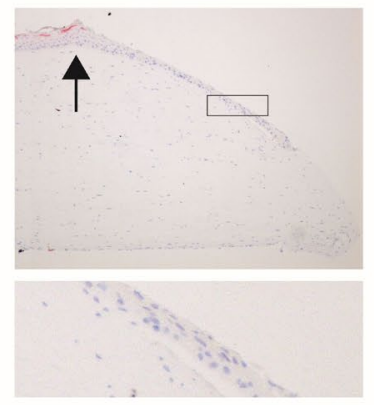
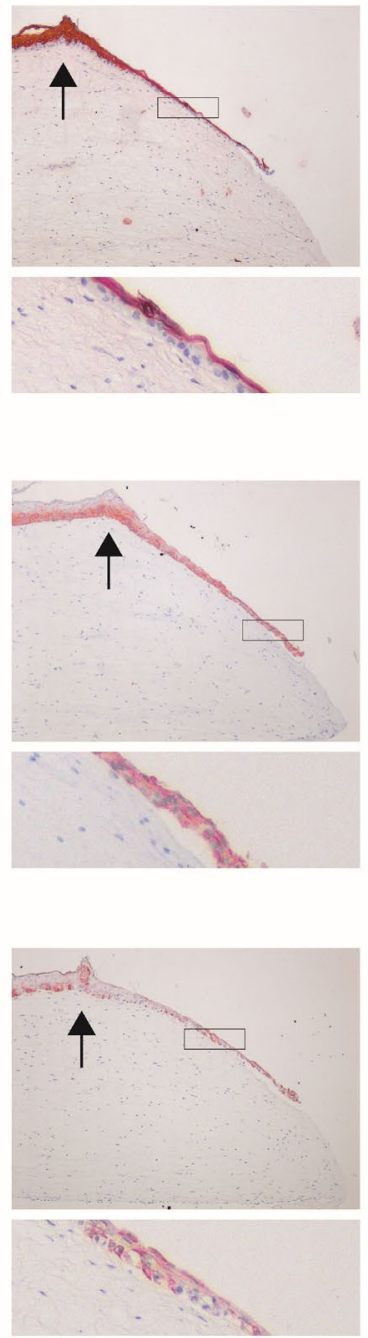

+ abutment b Keratin 6
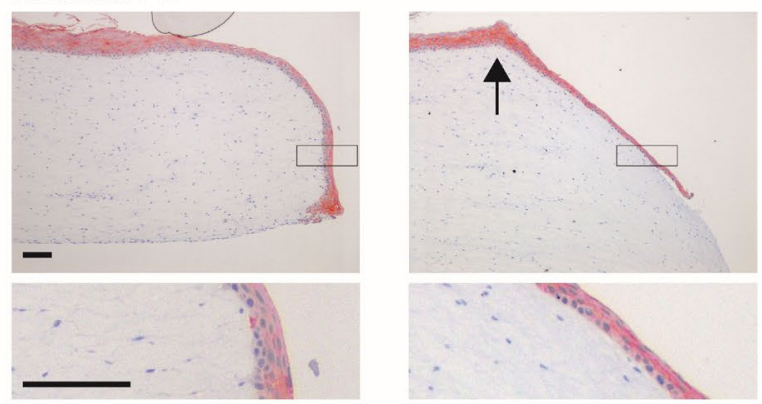

d Keratin 13
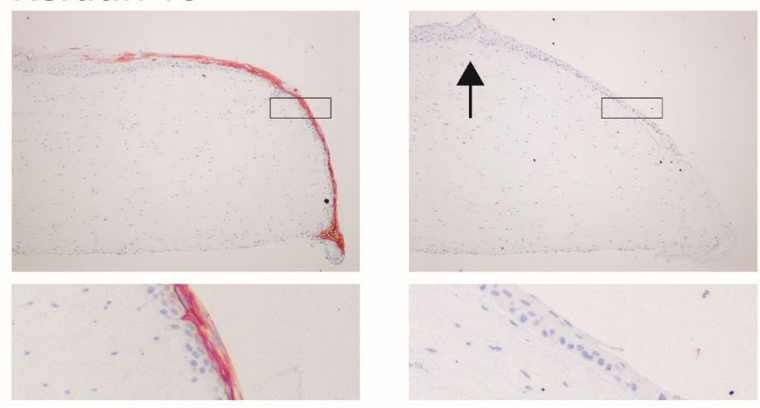

\section{f Keratin 16}
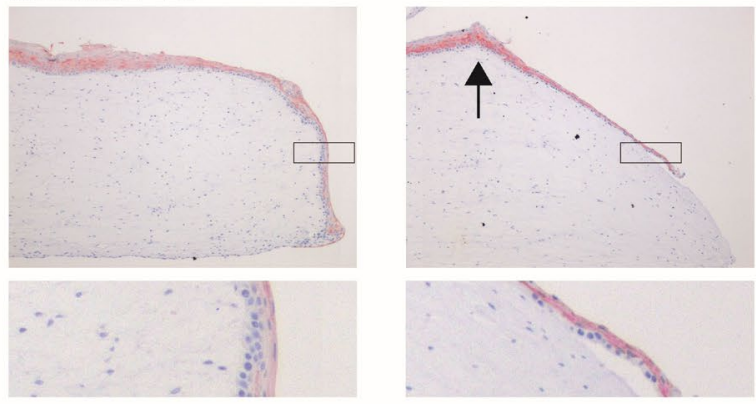

h Loricrin

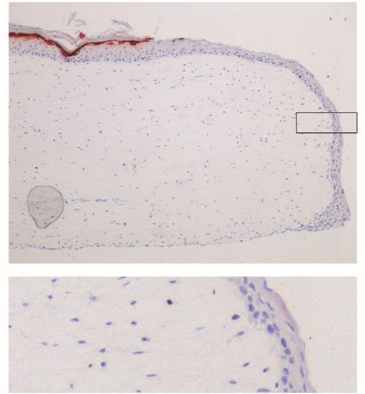

- abutment

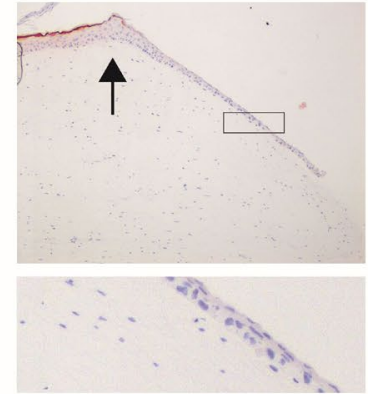

+ abutment

Fig. 4. RHG shows differential epithelial protein expression. An anodised titanium abutment inserted into an RHG, which is further cultured exposed to the air on a porous Transwell membrane for $10 \mathrm{~d}$. When the abutment is inserted into the model (+ abutment), the down-growing epithelium adjacent to titanium abutment surface adapts its phenotype to resemble a gingival margin, sulcular and junctional epithelium (right of arrow) and differentially expresses the associated physiological epithelial proteins (see K4, K14, K19, loricrin) (compare with Table 1 and Table 2). Furthermore, in the absence of the abutment (- abutment), epithelium retains K4 and K13 expression which is lost in RHG with abutment. Red = immune staining; scale bar $=100 \mu \mathrm{m}$. For full experimental details see Roffel et al. (2019). Unpublished data and data derived from Roffel et al. (2019) are shown. 
for preventing microbial colonisation (Rompen et al., 2006). Microbial colonisation impairs initial wound healing and may lead to chronic inflammation, bone resorption and implant failure (Hickok et al., 2018). Many studies have described the relationship between biofilm and peri-implant disease and investigated the physical-chemical properties of abutment materials with regards to implant success or failure (de Avila et al., 2014). Individuals with periodontal disease typically have many pathogenic microorganisms in the periodontal pocket. These remaining bacteria can adhere to the newly placed abutment and implant surfaces, eventually inducing peri-implant mucositis and progression to peri-implantitis, with destruction of the marginal bone close to the implant threads, and often causing subsequent implant loss. Therefore, it is clinically relevant to develop new material surfaces which will reduce or inhibit adhesion of pathogenic microorganisms (de Avila et al., 2014).

Soft tissue (epithelium and connective tissue) around dental abutments is elongated as compared to healthy gingiva around the tooth and this is thought to be due to a longer junctional epithelium, which contains fewer hemi-desmosomes (Iglhaut et al., 2014; Parpaiola et al., 2015; Sculean et al., 2014). Once the abutment has been placed, the oral epithelium rapidly migrates over the fibrin clot and contacts the abutment surface. As it migrates downwards parallel to the abutment surface, it phenotypically changes into a junctional epithelium (also known as peri-implant epithelium) and, depending on whether the properties of the abutment surface permit, the epithelium will attach to it. The downward migration of the junctional epithelium stops when it reaches the connective tissue (Rompen et al., 2006). In contrast to the perpendicular collagen fibres of Sharpey, which attach to the cementum of the tooth, the collagen fibre bundles run parallel to the abutment surface and may eventually surround the abutment. This resulting scarlike tissue has fewer fibroblasts and less vasculature than the connective tissue directly adjacent to the tooth (Schierano et al., 2002; Sculean et al., 2014). These important differences result in the abutment being less strongly attached to the connective tissue than the tooth. Consequently, mechanical load can cause shearing from the abutment surface, which in turn can lead to the junctional epithelium penetrating too in depth, reducing the area of connective tissue attachment and causing bone resorption (Rompen et al., 2006). Therefore, it is a key subject for research to develop surfaces that would enable junctional epithelium attachment to the abutment through an internal basal lamina and hemi-desmosomes whilst, simultaneously, allowing perpendicular collagen fibre bundle attachment to the abutment surface in order to prevent the junctional epithelium from migrating too in depth. Such a configuration would most closely resemble soft tissue attachment to the tooth. Consequently, increased attention is being paid to material characteristics such as surface chemistry, surface topography, micro-grooved surfaces, abutment macro- and micro-designs (Iglhaut et al., 2014), wettability (Gittens et al., 2014) and presence of biologically active proteins (Ma et al., 2012; Sugawara et al., 2016; van Dijk et al., 2017), which are all thought to influence the attachment of the junctional epithelium and connective tissue to the abutment surface.

An extensive evidence-based review by Linkevicius and Apse (2008) describes clinical and animal studies in which biological soft tissue width around abutments is assessed. The biological width is defined as the distance between the gingival margin and the alveolar bone and is approximately $2 \mathrm{~mm}$. Formation of the biological width and maturation of barrier function around the transmucosal abutment requires 6-8 weeks of healing (Sculean et al., 2014). It was concluded from the analysis of the included 2 clinical studies, 8 human histology studies and 4 animal studies (monkeys and dogs), published between 1980 and 2007, that information is predominantly animalbased and that there is insufficient information obtained from clinical controlled human studies. Histologically, biological width, consisting of sulcular and junctional epithelium with underlying connective tissue, is described in only 10 studies. Morphological high magnification details (e.g. transmission electron microscopy), showing the quality of epithelial attachment to the abutment surface e.g. through hemi-desmosome-like structures and internal basement membrane, are either not described or the studies have insufficient numbers of test subjects to be conclusive. Such important epithelial attachment details are required in order to assess whether a true biological seal occurs as opposed to when the epithelium simply migrates down the tissue surface adjacent to the abutment. The results from a limited number of studies are described below.

\section{Influence of abutment material surface features on cell and soft tissue attachment}

Previous studies have indicated that surface chemistry plays a major role in tissue-material interactions (Gasik, 2017). Chemical surface modifications of dental abutments to improve soft tissue attachment have recently emerged (Iglhaut et al., 2014). An overview of material characteristics under investigation is shown in Fig. 2. Among these modifications, techniques to tailor abutment surface wettability commonly quantified by contact angle have gained a lot of attention. The wettability of the surface can affect not only protein deposition and conformation but also, consequently, cell attachment and spreading (Gittens et al., 2014). While surface wettability depends on the surface chemical composition and structure, protein adsorption is only influenced by the surface hydrophilicity, correlating with the polarity of the surface functional groups (Liu et al., 2007). In general, the more hydrophilic a surface is the more proteins and other macromolecules attach to the surface (also called surface conditioning). Several in vitro studies have indicated that stronger 
hydrophilicity achieved by coating the titanium surface with more positively charged molecules, such as silver, can reduce bacterial adhesion (Lorenzetti et al., 2015). Oxygen plasma treatment of a surface to remove most of its contaminants can improve attachment and proliferation of human gingival fibroblasts (Lee et al., 2015).

Nanoporous titanium dioxide $\left(\mathrm{TiO}_{2}\right)$ surface modification, commonly used for dental implant systems, modifies not only the chemistry but also the pore structure and nanoscale topography of a surface (Jokinen et al., 1998; Macak et al., 2007). In vitro and clinical studies have reported beneficial effects of a $\mathrm{TiO}_{2}$ layer in soft tissue attachment. Dorkhan et al. (2014) showed in vitro that it is possible to reduce bacterial adherence to a nanoporous $\mathrm{TiO}_{2}$ surface, with a pore size below $50 \mathrm{~nm}$ and a thickness below $185 \mathrm{~nm}$, modified by anodic oxidation. Demetrescu et al. (2010) used anodised titanium discs to create $120 \mathrm{~nm}$-diameter nanotubes and increase the surface hydrophilicity. Gingival fibroblasts showed a slightly higher proliferation and adhesion rate on the samples with hydrophilic $\mathrm{TiO}_{2}$ nanotube surfaces as compared with non-anodised titanium surfaces. Similarly, Kim et al. $(2014 ;$ 2015) demonstrated that a titanium surface treated by anodic oxidation exhibits a higher gingival fibroblast attachment as compared with an untreated machined surface independently of the surface wettability. Examples of animal and clinical studies are described in more detail below.

Typically, epithelial down-growth on smooth titanium surfaces is approximately $2 \mathrm{~mm}$ as compared to approximately $1.6 \mathrm{~mm}$ adjacent to the tooth (Berglundh et al., 2007; Iglhaut et al., 2014; Lindhe and Berglundh, 1998). Abrahamsson et al. (2002) demonstrated in beagle dogs $(n=5)$ that the soft tissue attachment on titanium abutments is not influenced by the roughness of the titanium surface, e.g. an isotropic structure without any dominating direction (smooth) as compared to a strong anisotropy (acid etched), i.e. a well-defined orientation of the surface structure. However, Nevins et al. (2008; 2010; 2013) showed that tapered abutments with consistently formed micro-channels organise and promote tissue growth. A clinical study by Wennerberg et al. (2011) conducted on 15 patients indicated that micro-implant titanium surfaces, with a thin nanoporous $\mathrm{TiO}_{2}$ film obtained by the sol-gel technique as compared with machined surfaces, seem to improve the gingival contact to the abutment, as evaluated by light and transmission electron microscopy, with more soft tissue cells and fewer inflammatory cells at the interface. This surface modification results in a $\mathrm{TiO}_{2}$ layer with a thickness of about $380 \mathrm{~nm}$ and a pore size below $50 \mathrm{~nm}$ (Wennerberg et al., 2011). Similar results were obtained by Rossi and colleagues in a study with 6 beagle dogs. The authors observed a slightly increased soft tissue attachment by coating standard titanium implants with a thin film of nanoporous sol-gel-derived $\mathrm{TiO}_{2}$. This was concluded by assessing the biological width and length of the junctional epithelium rather than direct epithelial attachment to the abutment surface. A few hemidesmosome attachments to the abutment surface were observed but whether differences occurred between the coated and non-coated abutment was not described (Rossi et al., 2008). A $2 \mathrm{~mm}$ high micro-machined collar was designed to encourage bone and connective tissue attachment whilst, at the same time, preventing apical down-migration of the epithelium. Nevins et al. (2008), in a human study $(n=6)$, observed epithelial cells and extracellular matrix on the surface of removed abutments using scanning electron microscopy. Hemi-desmosome attachment of the epithelium through a basement membrane was not described, most probably due to limitations in the resolution of the techniques used to assess the tissues (Nevins et al., 2008). Abrahamsson et al. (1998), in a dog study $(n=5)$, observed that pure titanium and ceramic (highly sintered $\mathrm{Al}_{2} \mathrm{O}_{3}$ ) performed better than gold or gold alloys fused with dental porcelain, with the former showing a larger biological width, shorter junctional epithelium, better contact with soft tissue, less soft tissue recession and less bone resorption. Kohal et al. (2004), in a monkey study $(n=6)$, observed that custom-made zirconia abutments show the same peri-implant soft tissue dimensions and osseointegration as custom-made titanium abutments.

Taken together, even though these studies provide very important data, comprehensive scientific data on epithelial attachment to the abutment surface are still missing because, due to cost and ethical reasons, only small-scale experiments are performed in animals or humans.

\section{Molecular evaluation of soft tissue attachment to abutment surface}

Since only small-scale experiments can be performed in animals and humans, the number of available samples for analysis in currently described studies is limited (Abrahamsson et al., 2002; Kohal et al., 2004; Neiva et al., 2016; Nevins et al., 2010; Nevins et al., 2008; Rossi et al., 2008; Wennerberg et al., 2011). Since the downstream analysis dictates mutually exclusive fixation procedures, choices have been made with regard to what data are acquired (either general histology or ultrastructural features). Further technical challenges are associated with the sample content: the sample contains both hard and soft tissues, which have very different treatment and processing requirements. Finally, for standard immunohistochemical stainings on tissue sections of e.g. basement membrane components and cell attachment proteins (e.g. integrins), animal-specific antibodies for dogs and monkeys, the two wellestablished models for investigating tissue response to endosseous implants and abutments, are not available.

Recent developments in cell culture methodology have closed the gap between in vitro and in vivo models, allowing in vitro models to be used to 
obtain useful information on epithelial attachment to abutment surfaces. For example, using scanning electron microscopy and immunofluorescence microscopy with antibodies against vinculin and $\alpha 6 \beta 4$ integrin, Raisanen et al. (2000) showed in vitro that epithelial cells adhere and spread more rapidly on metallic surfaces (titanium, $\mathrm{Ti}_{6} \mathrm{Al}_{4} \mathrm{~V}$ titanium alloy, dental gold alloy) than on ceramic surfaces (dental porcelain and aluminium oxide). Well-organised focal contacts and pre-hemi-desmosomes were found on metallic surfaces, but not on porcelain and aluminium oxide (Raisanen et al., 2000). In line with these findings, hemidesmosome-like structures and extracellular matrix contacts between epithelial cells and titanium, gold, hydroxyapatite and carbon apatite have been described (Jansen et al., 1985; Kaster et al., 1990). Since dental research has traditionally focused on hard tissue interactions with the tooth or implant, until now, most of these methods only explored mesenchymal cells and cell lines but not epithelial keratinocytes and, therefore, the findings need to be interpreted with care since in vivo fibroblasts do not directly attach to the abutment surface, in contrast to the extracellular matrix and the keratinocytes of the junctional epithelium.

More recently, organotypic-reconstructed human gingiva models have been described for investigating epithelial attachment to abutment surfaces (Fig. 3). These models typically consist of a differentiated, stratified oral epithelium on a fibroblast-populated matrix (collagen hydrogel or donor dermis), which serves as the lamina propria (Buskermolen et al., 2016; Moharamzadeh et al., 2007; Moharamzadeh et al., 2012). Keratinocytes and fibroblasts are derived from primary tissue sources or cell lines, the latter of which greatly increases scalability of experiments (Buskermolen et al., 2016). Due to the 3D structure, the model can be used for the evaluation of soft tissue attachment to different abutment surfaces at the histomorphometric, scanning electron microscope and immunohistochemical level (unpublished data, Fig. 3 and Fig. 4; Chai et al., 2010; Roffel et al., 2019). Similar histomorphometric criteria to those used in animal and clinical studies could be used to assess sulcus depth, junctional epithelium length and gingiva height (Roffel et al., 2019). Notably, when an abutment is inserted into the model, the down-growing epithelium adjacent to titanium abutment surfaces adapts its phenotype to resemble a gingival margin, sulcular and junctional epithelium and differentially expresses the associated physiological epithelial proteins (keratins: K4, K6, $\mathrm{K} 13, \mathrm{~K} 14, \mathrm{~K} 19$; loricrin) as well as internal and external basement membrane proteins (collagen IV, laminin 5) (unpublished data; Roffel et al., 2019) (compare Fig. 3 and Fig. 4 with Table 1 and Table 2). Moreover, the down-growing epithelium adjacent to the abutment surface resembles more closely junctional epithelium than epithelium formed during gingival epithelium wound healing as seen by the differential expression of K4 and K13, which are absent in junctional epithelium as compared to cultures where no abutment is placed (Fig. 4) (unpublished data). The value of this model is further emphasised by recent pre-clinical and clinical studies in which the same two abutment surfaces (a nanostructured anodised surface and a machined titanium abutment) were compared in a randomised, controlled clinical study ( $n=35 ; 2$ different abutments/ implants per patient; 2 years follow-up), a Yucatan mini-pig study $(n=12 ; 3$ abutments/implants of same sort per pig; 13 weeks follow-up) and a study using the organotypic-reconstructed human gingiva ( 3 independent experiments each with 44 gingiva cultures per batch; 10 day follow-up) (Hall et al., 2019; Roffel et al., 2019; Susin et al., 2019). Very complimentary results were obtained among these studies. Both the reconstructed human gingiva and the mini-pig studies concluded that no difference between the abutment surfaces is observed with regards to the junctional epithelium attachment to the abutment surface (epithelium length, mucosa height). The clinical study showed that the anodised and nanostructured surface results in a higher keratinised gingiva than the conventional machined titanium surface. Another study using reconstructed human gingiva investigated the quality of the biological seal of four different Ti surfaces [polished, machined, sandblasted and anodised (TiUnite)] by determining the permeability to tritiated water (Chai et al., 2012). In the future, it may be possible to investigate the quality of the biological seal after exposure to commensal and pathogenic multi-species biofilm to further increase the physiological relevance of the model (Buskermolen et al., 2018; Shang et al., 2018). Taken together, organotypic culture models can exhibit features representative of human oral mucosa epithelium attachment to an abutment surface and may provide a novel preclinical means to investigate different abutment surfaces in the future.

\section{Conclusions and future perspectives}

Previous research on implant and abutment development has been directed mainly towards achieving optimal implant embedment into bone. Fewer studies have described soft tissue attachment to the abutment surface. Most studies evaluating soft tissue attachment focus on connective tissue attachment, with only few studies describing epithelial attachment. Epithelial attachment to the abutment surface is necessary to form the biological seal preventing pathogens from penetrating the underlying soft tissues and bone. Further research needs to focus on the material physical and chemical properties to enhance epithelial attachment. Since animal studies are extremely limited due to ethical considerations and costs as well as lack of tools and techniques, only a few animals are included in current studies with limited read-out parameters. No detailed studies reporting the extent of junctional 
epithelium attachment e.g. hemi-desmosomes, epithelium quality, composition of the external basement membrane or ability of the epithelium to resist microbial penetration and colonisation are available. While in vitro studies generally involve relatively simple $2 \mathrm{D}$ culture models, they lack the complexity required to draw relevant conclusions. Human organotypic gingiva 3D in vitro models may overcome some of these restrictions and, therefore, open new opportunities for research.

In the future, more research regarding the interaction of soft tissue and abutments using models ranging from human organotypic 3D in vitro models to clinical cases may help us to better understand the relevant parameters involved in these interactions.

\section{Acknowledgements}

The study was financed in part by Nobel Biocare Services AG. SG and SR have no conflicts of interest to declare; MM and AG are employees of Nobel Biocare.

\section{References}

Abrahamsson I, Berglundh T, Glantz PO, Lindhe J (1998) The mucosal attachment at different abutments. An experimental study in dogs. J Clin Periodontol 25: 721-727.

Abrahamsson I, Zitzmann NU, Berglundh T, Linder E, Wennerberg A, Lindhe J (2002) The mucosal attachment to titanium implants with different surface characteristics: an experimental study in dogs. J Clin Periodontol 29: 448-455.

Amerongen AV, Veerman EC (2002) Saliva-the defender of the oral cavity. Oral Dis 8: 12-22.

Angeletti LR, Agrimi U, Curia C, French D, Mariani-Costantini R (1992) Healing rituals and sacred serpents. Lancet 340: 223-225.

Ashcroft GS, Lei K, Jin W, Longenecker G, Kulkarni AB, Greenwell-Wild T, Hale-Donze H, McGrady G, Song XY, Wahl SM (2000) Secretory leukocyte protease inhibitor mediates non-redundant functions necessary for normal wound healing. Nat Med 6: 1147-1153.

Barrientos S, Stojadinovic O, Golinko MS, Brem H, Tomic-Canic M (2008) Growth factors and cytokines in wound healing. Wound Repair Regen 16: 585-601.

Barros SP, Williams R, Offenbacher S, Morelli $\mathrm{T}$ (2016) Gingival crevicular fluid as a source of biomarkers for periodontitis. Periodontol 2000 70: 53-64.

Berglundh T, Abrahamsson I, Welander M, Lang NP, Lindhe J (2007) Morphogenesis of the periimplant mucosa: an experimental study in dogs. Clin Oral Implants Res 18: 1-8.

Berglundh T, Jepsen S, Stadlinger B, Terheyden H (2019) Peri-implantitis and its prevention. Clin Oral Implants Res 30: 150-155.
Bielemann AM, Marcello-Machado RM, Del Bel Cury AA, Faot F (2018) Systematic review of wound healing biomarkers in peri-implant crevicular fluid during osseointegration. Arch Oral Biol 89: 107-128.

Bodner L, Dayan D (1995) Epithelium and connective tissue regeneration during palatal wound healing in desalivated rats -- a comparative study. Comp Biochem Physiol A Physiol 111: 415-419.

Bodner L, Kaffe I, Cohen Z, Dayan D (1993) Long-term effect of desalivation on extraction wound healing: a densitometric study in rats. Dentomaxillofac Radiol 22: 195-198.

Boink MA, Roffel S, Breetveld M, Thon M, Haasjes MSP, Waaijman T, Scheper RJ, Blok CS, Gibbs S (2018) Comparison of advanced therapy medicinal product gingiva and skin substitutes and their in vitro wound healing potentials. J Tissue Eng Regen Med 12: e1088-e1097.

Boink MA, Roffel S, Nazmi K, Bolscher JGM, Veerman ECI, Gibbs S (2017) Saliva-derived host defense peptides histatin1 and 11-37 increase secretion of antimicrobial skin and oral mucosa chemokine CCL20 in an IL-1alpha-independent manner. J Immunol Res 2017: 3078194. DOI: $10.1155 / 2017 / 3078194$.

Boink MA, van den Broek LJ, Roffel S, Nazmi K, Bolscher JG, Gefen A, Veerman EC, Gibbs S (2016) Different wound healing properties of dermis, adipose, and gingiva mesenchymal stromal cells. Wound Repair Regen 24: 100-109.

Bosshardt DD, Lang NP (2005) The junctional epithelium: from health to disease. J Dent Res 84: 9-20.

Bosshardt DD, Stadlinger B, Terheyden H (2015) Cell-to-cell communication - periodontal regeneration. Clin Oral Implants Res 26: 229-239.

Brand HS, Ligtenberg AJ, Veerman EC (2014) Saliva and wound healing. Monogr Oral Sci 24: 52-60.

Buskermolen JK, Janus MM, Roffel S, Krom BP, Gibbs S (2018) Saliva-derived commensal and pathogenic biofilms in a human gingiva model. J Dent Res 97: 201-208.

Buskermolen JK, Reijnders CM, Spiekstra SW, Steinberg T, Kleverlaan CJ, Feilzer AJ, Bakker AD, Gibbs S (2016) Development of a full-thickness human gingiva equivalent constructed from immortalized keratinocytes and fibroblasts. Tissue Eng Part C Methods 22: 781-791.

Buskermolen JK, Roffel S, Gibbs S (2017) Stimulation of oral fibroblast chemokine receptors identifies CCR3 and CCR4 as potential wound healing targets. J Cell Physiol 232: 2996-3005.

Chai WL, Brook IM, Palmquist A, van Noort R, Moharamzadeh K (2012) The biological seal of the implant-soft tissue interface evaluated in a tissueengineered oral mucosal model. J R Soc Interface 9: 3528-3538.

Chai WL, Moharamzadeh K, Brook IM, Emanuelsson L, Palmquist A, van Noort R (2010) Development of a novel model for the investigation of implant-soft tissue interface. J Periodontol 81: 11871195. 
Chen L, Arbieva ZH, Guo S, Marucha PT, Mustoe TA, DiPietro LA (2010) Positional differences in the wound transcriptome of skin and oral mucosa. BMC Genomics 11: 471. DOI: 10.1186/1471-2164-11-471.

Dawes C, Pedersen AM, Villa A, Ekstrom J, Proctor GB, Vissink A, Aframian D, McGowan R, Aliko A, Narayana N, Sia YW, Joshi RK, Jensen SB, Kerr AR, Wolff A (2015) The functions of human saliva: a review sponsored by the World Workshop on Oral Medicine VI. Arch Oral Biol 60: 863-874.

Dayan D, Bodner L, Horowitz I (1992) Effect of salivary gland hypofunction on the healing of extraction wounds: a histomorphometric study in rats. J Oral Maxillofac Surg 50: 354-358.

de Avila ED, de Molon RS, Vergani CE, de Assis Mollo F Jr, Salih V (2014) The relationship between biofilm and physical-chemical properties of implant abutment materials for successful dental implants. Materials (Basel) 7: 3651-3662.

Demetrescu I, Pirvu C, Mitran V (2010) Effect of nano-topographical features of $\mathrm{Ti} / \mathrm{TiO}(2)$ electrode surface on cell response and electrochemical stability in artificial saliva. Bioelectrochemistry 79: 122-129.

Dorkhan M, Hall J, Uvdal P, Sandell A, Svensater G, Davies JR (2014) Crystalline anatase-rich titanium can reduce adherence of oral streptococci. Biofouling 30: 751-759.

Ellebrecht CT, Srinivas G, Bieber K, Banczyk D, Kalies K, Kunzel S, Hammers CM, Baines JF, Zillikens D, Ludwig RJ, Westermann J (2016) Skin microbiota-associated inflammation precedes autoantibody induced tissue damage in experimental epidermolysis bullosa acquisita. J Autoimmun 68: 14-22.

Engeland CG, Bosch JA, Cacioppo JT, Marucha PT (2006) Mucosal wound healing: the roles of age and sex. Arch Surg 141: 1193-1198.

Faot F, Nascimento GG, Bielemann AM, Campao TD, Leite FR, Quirynen M (2015) Can peri-implant crevicular fluid assist in the diagnosis of periimplantitis? A systematic review and meta-analysis. J Periodontol 86: 631-645.

Feller L, Altini M, Khammissa RA, Chandran R, Bouckaert M, Lemmer J (2013) Oral mucosal immunity. Oral Surg Oral Med Oral Pathol Oral Radiol 116: 576-583.

Gasik M (2017) Understanding biomaterial-tissue interface quality: combined in vitro evaluation. Sci Technol Adv Mater 18: 550-562.

Ghosh SK, Gupta S, Jiang B, Weinberg A (2011) Fusobacterium nucleatum and human beta-defensins modulate the release of antimicrobial chemokine CCL20/macrophage inflammatory protein 3alpha. Infect Immun 79: 4578-4587.

Gibbs S, Ponec M (2000) Intrinsic regulation of differentiation markers in human epidermis, hard palate and buccal mucosa. Arch Oral Biol 45: 149-158.

Gittens RA, Scheideler L, Rupp F, Hyzy SL, GeisGerstorfer J, Schwartz Z, Boyan BD (2014) A review on the wettability of dental implant surfaces II: biological and clinical aspects. Acta Biomater 10: 2907-2918.
Glim JE, van Egmond M, Niessen FB, Everts V, Beelen RH (2013) Detrimental dermal wound healing: what can we learn from the oral mucosa? Wound Repair Regen 21: 648-660.

Hall J, Neilands J, Davies JR, Ekestubbe A, Friberg B (2019) A randomized, controlled, clinical study on a new titanium oxide abutment surface for improved healing and soft tissue health. Clin Implant Dent Relat Res 21 Suppl 1: 55-68.

Hammerle CH, Araujo MG, Simion M, Osteology Consensus G (2012) Evidence-based knowledge on the biology and treatment of extraction sockets. Clin Oral Implants Res 23 Suppl 5: 80-82.

Hammerle CH, Giannobile WV, Working Group 1 of the European Workshop on Periodontology.(2014) Biology of soft tissue wound healing and regeneration - consensus report of Group 1 of the 10th European Workshop on Periodontology. J Clin Periodontol 41 Suppl 15: S1-5.

Henskens YM, van den Keijbus PA, Veerman EC, Van der Weijden GA, Timmerman MF, Snoek CM, Van der Velden U, Nieuw Amerongen AV (1996) Protein composition of whole and parotid saliva in healthy and periodontitis subjects. Determination of cystatins, albumin, amylase and IgA. J Periodontal Res 31: 57-65.

Hickok NJ, Shapiro IM, Chen AF (2018) The impact of incorporating antimicrobials into implant surfaces. J Dent Res 97: 14-22.

Iglesias-Bartolome R, Uchiyama A, Molinolo AA, Abusleme L, Brooks SR, Callejas-Valera JL, Edwards D, Doci C, Asselin-Labat ML, Onaitis MW, Moutsopoulos NM, Gutkind JS, Morasso MI (2018) Transcriptional signature primes human oral mucosa for rapid wound healing. Sci Transl Med 10. pii: eaap8798. DOI: 10.1126/scitranslmed.aap8798.

Iglhaut G, Schwarz F, Winter RR, Mihatovic I, Stimmelmayr M, Schliephake H (2014) Epithelial attachment and downgrowth on dental implant abutments - a comprehensive review. J Esthet Restor Dent 26: 324-331.

Jahovic N, Guzel E, Arbak S, Yegen BC (2004) The healing-promoting effect of saliva on skin burn is mediated by epidermal growth factor (EGF): role of the neutrophils. Burns 30: 531-538.

Jansen J A, de Wijn JR, Wolters-Lutgerhorst JM, van MullemPJ (1985) Ultrastructural study of epithelial cell attachment to implant materials. J Dent Res 64: 891-896.

Janus MM, Keijser BJ, Bikker FJ, Exterkate RA, Crielaard W, Krom BP (2015) In vitro phenotypic differentiation towards commensal and pathogenic oral biofilms. Biofouling 31: 503-510.

Jiang Q, Yu Y, Ruan H, Luo Y, Guo X (2014) Morphological and functional characteristics of human gingival junctional epithelium. BMC Oral Health 14: 30. DOI: 10.1186/1472-6831-14-30.

Jokinen M, Patsi M, Rahiala H, Peltola T, Ritala M, Rosenholm JB (1998) Influence of sol and surface properties on in vitro bioactivity of sol-gel-derived $\mathrm{TiO} 2$ and $\mathrm{TiO} 2-\mathrm{SiO} 2$ films deposited by dip-coating method. J Biomed Mater Res 42: 295-302. 
Kannon GA, Garrett AB (1995) Moist wound healing with occlusive dressings. A clinical review. Dermatol Surg 21: 583-590.

Kasten FH, Soileau K, Meffert RM (1990) 'Quantitative evaluation of human gingival epithelial cell attachment to implant surfaces in vitro. Int J Periodontics Restorative Dent 10: 68-79.

Khan A, Shirlaw PJ (2016) Dry mouth and Sjogren's syndrome: an overview. Prim Dent J 5: 7074.

Kim YS, Ko Y, Kye SB, Yang SM (2014) Human gingival fibroblast (HGF-1) attachment and proliferation on several abutment materials with various colors. Int J Oral Maxillofac Implants 29: 969-975.

Kim YS, Shin SY, Moon SK, Yang SM (2015) Surface properties correlated with the human gingival fibroblasts attachment on various materials for implant abutments: a multiple regression analysis. Acta Odontol Scand 73: 38-47.

Koczulla R, von Degenfeld G, Kupatt C, Krotz F, Zahler S, Gloe T, Issbrucker K, Unterberger P, Zaiou M, Lebherz C, Karl A, Raake P, Pfosser A, Boekstegers P, Welsch U, Hiemstra PS, Vogelmeier C, Gallo RL, Clauss M, Bals R (2003) An angiogenic role for the human peptide antibiotic LL-37/hCAP-18. J Clin Invest 111: 1665-1672.

Kohal RJ, Weng D, Bachle M, Strub JR (2004) Loaded custom-made zirconia and titanium implants show similar osseointegration: an animal experiment. J Periodontol 75: 1262-1268.

Kosten IJ, Buskermolen JK, Spiekstra SW, de Gruijl TD, Gibbs S (2015) Gingiva equivalents secrete negligible amounts of key chemokines involved in langerhans cell migration compared to skin equivalents. J Immunol Res 2015: 627125. DOI: $10.1155 / 2015 / 627125$.

Kosten IJ, van de Ven R, Thon M, Gibbs S, de Gruijl TD (2017) Comparative phenotypic and functional analysis of migratory dendritic cell subsets from human oral mucosa and skin. PLoS One 12: e0180333. DOI: 10.1371/journal.pone.0180333.

Kroeze KL, Boink MA, Sampat-Sardjoepersad SC, Waaijman T, Scheper RJ, Gibbs S (2012) Autocrine regulation of re-epithelialization after wounding by chemokine receptors CCR1, CCR10, CXCR1, CXCR2, and CXCR3. J Invest Dermatol 132: 216-225.

Krom BP, Oskam J (2014) Microbial biofilms and wound healing: an ecological hypothesis. Phlebology 29: 168-173.

Lang NP, Lindhe J (2015) Clinical periodontology and implant dentistry. $6^{\text {th }}$ Edition. Wiley-Blackwell.

Larjava H, Koivisto L, Hakkinen L, Heino J (2011a) Epithelial integrins with special reference to oral epithelia. J Dent Res 90: 1367-1376.

Larjava H, Wiebe C, Gallant-Behm C, Hart DA, Heino J, Hakkinen L (2011b) Exploring scarless healing of oral soft tissues. J Can Dent Assoc 77: b18.

Lee JH, Kim YH, Choi EH, Kim KM, Kim KN (2015) Air atmospheric-pressure plasma-jet treatment enhances the attachment of human gingival fibroblasts for early peri-implant soft tissue seals on titanium dental implant abutments. Acta Odontol Scand 73: 67-75.

Lindhe J, Berglundh T (1998) The interface between the mucosa and the implant. Periodontol 2000 17: 47-54.

Linkevicius T, Apse P (2008) Biologic width around implants. An evidence-based review. Stomatologija 10: 27-35.

Liu X, Lim JY, Donahue HJ, Dhurjati R, Mastro AM, Vogler EA (2007) Influence of substratum surface chemistry/energy and topography on the human fetal osteoblastic cell line hFOB 1.19: phenotypic and genotypic responses observed in vitro. Biomaterials 28: 4535-4550.

Lorenzetti M, Dogsa I, Stosicki T, Stopar D, Kalin M, Kobe S, Novak S (2015) The influence of surface modification on bacterial adhesion to titanium-based substrates. ACS Appl Mater Interfaces 7: 1644-1651.

Ma Q, Wang W, Chu PK, Mei S, Ji K, Jin L, Zhang Y (2012) Concentration- and time-dependent response of human gingival fibroblasts to fibroblast growth factor 2 immobilized on titanium dental implants. Int J Nanomedicine 7: 1965-1976.

Macak JM, Zlamal M, Krysa J, Schmuki P (2007) Self-organized TiO2 nanotube layers as highly efficient photocatalysts. Small 3: 300-304.

Mohanty T, Sjogren J, Kahn F, Abu-Humaidan AH, Fisker N, Assing K, Morgelin M, Bengtsson AA, Borregaard N, Sorensen OE (2015) A novel mechanism for NETosis provides antimicrobial defense at the oral mucosa. Blood 126: 2128-2137.

Moharamzadeh K, Brook IM, Van Noort R, Scutt AM, Thornhill MH (2007) Tissue-engineered oral mucosa: a review of the scientific literature. J Dent Res 86: 115-124.

Moharamzadeh K, Colley $\mathrm{H}$, Murdoch C, Hearnden V, Chai WL, Brook IM, Thornhill MH, Macneil S (2012) Tissue-engineered oral mucosa. J Dent Res 91: 642-650.

Neiva R, Tovar N, Jimbo R, Gil LF, Goldberg P, Barbosa JP, Lilin T, Coelho PG (2016) the effect of laser-etched surface design on soft tissue healing of two different implant abutment systems: an experimental study in dogs. Int J Periodontics Restorative Dent 36: 673-679.

Nevins M, Kim DM, Jun SH, Guze K, Schupbach P, Nevins ML (2010) Histologic evidence of a connective tissue attachment to laser microgrooved abutments: a canine study. Int J Periodontics Restorative Dent 30: 245-255.

Nevins M, Nevins M, Gobbato L, Lee HJ, Wang CW, Kim DM (2013) Maintaining interimplant crestal bone height via a combined platform-switched, LaserLok implant/abutment system: a proof-of-principle canine study. Int J Periodontics Restorative Dent 33: 261-267.

Nevins M, Nevins ML, Camelo M, Boyesen JL, Kim DM (2008) Human histologic evidence of a connective tissue attachment to a dental implant. Int J Periodontics Restorative Dent 28: 111-121. 
Oppenheim FG, Xu T, McMillian FM, Levitz SM, Diamond RD, Offner GD, Troxler RF (1988) Histatins, a novel family of histidine-rich proteins in human parotid secretion. Isolation, characterization, primary structure, and fungistatic effects on Candida albicans. J Biol Chem 263: 7472-7477.

Oudhoff MJ, Bolscher JG, Nazmi K, Kalay H, van 't Hof W, Amerongen AV, Veerman EC (2008) Histatins are the major wound-closure stimulating factors in human saliva as identified in a cell culture assay. FASEB J 22: 3805-3812.

Padovan L, Segat L, Pontillo A, Antcheva N, Tossi A, Crovella S (2010) Histatins in non-human primates: gene variations and functional effects. Protein Pept Lett 17: 909-918.

Parpaiola A, Cecchinato D, Toia M, Bressan E, Speroni S, Lindhe J (2015) Dimensions of the healthy gingiva and peri-implant mucosa. Clin Oral Implants Res 26: 657-662.

Playford RJ, Macdonald CE (1997) Growth factors in saliva. Lancet 350: 369-369.

Presland RB, Dale BA (2000) Epithelial structural proteins of the skin and oral cavity: function in health and disease. Crit Rev Oral Biol Med 11: 383-408.

Presland RB, Jurevic RJ (2002) Making sense of the epithelial barrier: what molecular biology and genetics tell us about the functions of oral mucosal and epidermal tissues. J Dent Educ 66: 564-574.

Prodan A, Brand HS, Ligtenberg AJM, Imangaliyev S, Tsivtsivadze E, van der Weijden F, Crielaard W, Keijser BJF, Veerman ECI (2015) Interindividual variation, correlations, and sex-related differences in the salivary biochemistry of young healthy adults. Eur J Oral Sci 123: 149-157.

Raisanen L, Kononen M, Juhanoja J, Varpavaara P, Hautaniemi J, Kivilahti J, Hormia M (2000) Expression of cell adhesion complexes in epithelial cells seeded on biomaterial surfaces. J Biomed Mater Res 49: 79-87.

Roffel S, Wu G, Nedeljkovic I, Meyer M, Razafiarison T, Gibbs S (2019) Evaluation of a novel oral mucosa in vitro implantation model for analysis of molecular interactions with dental abutment surfaces. Clin Implant Dent Relat Res 21 Suppl 1: 25-33.

Rompen E, Domken O, Degidi M, Pontes AEF, Piattelli A (2006) The effect of material characteristics, of surface topography and of implant components and connections on soft tissue integration: a literature review. Clin Oral Implan Res 17: 55-67.

Rossi S, Tirri T, Paldan H, Kuntsi-Vaattovaara H, Tulamo R, Narhi T (2008) Peri-implant tissue response to $\mathrm{TiO} 2$ surface modified implants. Clin Oral Implan Res 19: 348-355.

Salvi GE, Bosshardt DD, Lang NP, Abrahamsson I, Berglundh T, Lindhe J, Ivanovski S, Donos N (2015) Temporal sequence of hard and soft tissue healing around titanium dental implants. Periodontol 2000 68: 135-152.

Schierano G, Ramieri G, Cortese M, Aimetti M, Preti G (2002) Organization of the connective tissue barrier around long-term loaded implant abutments in man. Clin Oral Implants Res 13: 460-464.

Schlecht LM, Peters BM, Krom BP, Freiberg JA, Haensch GM, Filler SG, Jabra-Rizk MA, Shirtliff' ME (2015) Systemic Staphylococcus aureus infection mediated by Candida albicans hyphal invasion of mucosal tissue. Microbiol-Sgm 161: 168-181.

Sculean A, Gruber R, Bosshardt DD (2014) Soft tissue wound healing around teeth and dental implants. J Clin Periodontol 41: S6-S22.

Shang L, Deng D, Buskermolen JK, Janus MM, Krom BP, Roffel S, Waaijman T, van Loveren C, Crielaard W, Gibbs S (2018) Multi-species oral biofilm promotes reconstructed human gingiva epithelial barrier function. Scientific reports 8: 16061. DOI: 10.1038/s41598-018-34390-y.

Srinivas G, Moller S, Wang J, Kunzel S, Zillikens D, Baines JF, Ibrahim SM (2013) Genome-wide mapping of gene-microbiota interactions in susceptibility to autoimmune skin blistering. Nat Commun 4. DOI: 10.1038/ncomms3462.

Sugawara S, Maeno M, Lee C, Nagai S, Kim DM, Da Silva J, Nagai M, Kondo H (2016) Establishment of epithelial attachment on titanium surface coated with platelet activating peptide. PLoS One 11. DOI: 10.1371/journal.pone.0164693.

Susin C, Finger Stadler A, Fiorini T, de Sousa Rabelo M, Ramos UD, Schupbach P (2019) Safety and efficacy of a novel anodized abutment on soft tissue healing in Yucatan mini-pigs. Clin Implant Dent Relat Res 21 Suppl 1: 34-43.

Szpaderska AM, Walsh CG, Steinberg MJ, DiPietro LA (2005) Distinct patterns of angiogenesis in oral and skin wounds. J Dent Res 84: 309-314.

Szpaderska AM, Zuckerman JD, DiPietro LA (2003) Differential injury responses in oral mucosal and cutaneous wounds. J Dent Res 82: 621-626.

Tomasi C, Tessarolo F, Caola I, Piccoli F, Wennstrom JL, Nollo G, Berglundh T (2016) Early healing of peri-implant mucosa in man. J Clin Periodontol 43: 816-824.

Trengove NJ, Stacey MC, McGechie DF, Mata S (1996) Qualitative bacteriology and leg ulcer healing. J Wound Care 5: 277-280.

van Dijk IA, Beker AF, Jellema W, Nazmi K, Wu G, Wismeijer D, Krawczyk PM, Bolscher JG, Veerman EC, Stap J (2017) Histatin 1 enhances cell adhesion to titanium in an implant integration model. J Dent Res 96: 430-436.

Vriens AP, Waaijman T, van den Hoogenband HM, de Boer EM, Scheper RJ, Gibbs S (2008) Comparison of autologous full-thickness gingiva and skin substitutes for wound healing. Cell Transplant 17: 1199-1209.

Wennerberg A, Frojd V, Olsson M, Nannmark U, Emanuelsson L, Johansson P, Josefsson Y, Kangasniemi I, Peltola T, Tirri T, Pankalainen T, Thomsen P (2011) Nanoporous $\mathrm{TiO}(2)$ thin film on titanium oral implants for enhanced human soft tissue adhesion: a light and electron microscopy study. Clin Implant Dent Relat Res 13: 184-196. 
Winning TA, Townsend GC (2000) Oral mucosal embryology and histology. Clin Dermatol 18: 499-511.

Zaura E, Nicu EA, Krom BP, Keijser BJ (2014) Acquiring and maintaining a normal oral microbiome: current perspective. Front Cell Infect Microbiol 4: 85. DOI: $10.3389 /$ fcimb.2014.00085.

\section{Discussion with Reviewers}

Piefrancesco Pagella: What do you think would be a game-changer for epithelial adhesion/seal? Material properties, directing epithelial cells to specific fates/ behaviours?

Authors: Indeed, the game-changer would be to develop material properties which direct epithelial cells to specific fates e.g. strong attachment to the abutment surface.

Editor's note: The Scientific Editor responsible for this paper was Thimios Mitsiadis. 